\title{
ANALISIS KEUNTUNGAN PADA INDUSTRI RUMAH TANGGA PENGOLAH IKAN DI KECAMATAN SAMATIGA KABUPATEN ACEH BARAT
}

\author{
Nabila Ukhty \\ Perikanan, Fakultas Perikanan dan Ilmu Kelautan Universitas Teuku Umar \\ nabila@utu.ac.id
}

\begin{abstract}
Abstrak
Salting fish is a food a reatively cheap and has good nutritional content. Request Fish every day and the Vilage of Kuala Bubon Kabupaten Aceh Barat Kecamatan Samatiga is quite higt, many buyers who buy fish to be used as a side dish food suplplement that can increase profits for businesses dried fish. This study aims to determine how much cost is issued the pocess of salted fish to the fish processing buiness profit in the District of South Kuala Bubon. This research used primary data obtained from direct interview. Responden were interviewed are entrepreneurs household fish processing industry in the District of South Kuala Bubon with a sample of 30 respondents amounted to the designated purpose. Data analysis techhniques used are qualitative descriptive. Research findings indicate operated processing home industry become fish anchovies every month issued a cover fee of Rp.2.617.202 while home industry acceptance emounted Rp.3.953.333. General operating profit home industry of salted fish processing is Rp.1.336.13.
\end{abstract}

Key Word :, Cost, business Profit, home industry salted fish

\section{PENDAHULUAN}

Ikan merupakan salah satu komoditi yang berperan penting dalam kehidupan manusia. Perikanan seperti halnya sektor perekonomian lainnya, merupakan salah satu aktivitas yang memberikan kontribusi terhadap kesejahteraan suatu bangsa. Sebagai salah satu sumber daya alam yang bersifat dapat diperbaharui (renewable), pengelolaan sumber daya alam ini memerlukan pendekatan yang bersifat menyeluruh dan hati-hati (Akhmad, Fauzi 2004).

Keuntungan dari hasil ikan juga merupakan sebagian dari pembangunan ekonomi di Provinsi Riau, dimana Provinsi Riau yang terdiri dari daerah perairan yang mengandung sumber daya ikan yang sangat banyak dari segi keanekaragaman jenisnya dan sangat tinggi dari segi tingkat kesuburan. Kabupaten Aceh Barat ini tepatnya di Desa Kuala Bubon Kecamatan Samatiga merupakan salah satu tempat penghasil ikan yang mengelola ikan asin guna untuk mendapatkan keuntungan.

Pengelolaan ikan yang berkelanjutan dapat meningkatkan nilai tambah ikan pada industri rumah tangga pengolahan ikan di Desa Kuala Bubon yang dapat memberikan kontribusi yang signifikan dalam mencapai tujuan untuk memperoleh keuntungan yang lebih besar pada industri rumah tangga tersebut. Namun dari hasil observasi pendahuluan pada umumnya pendapatan dari hasil keuntungan penjualan ikan asin pada industri rumah tangga ikan asin di Desa Kuala Bubon Kecamatan Samatiga ini masih rendah, tidak sedikit pengolahan ikan asin dalam industri rumah tangga yang taraf hidupnya masih sederhana karena hasil produksi ikan asin yang kurang memuaskan. Produksi diartikan sebagai hasil akhir dari proses atau aktivitas ekonomi dengan memanfaatkan beberapa masukan atau 
input. Produksi juga diartikan sebagai kegiatan untuk meningkatkan suatu barang (Soeharno,2017).

Hasil produksi yang kurang memuaskan akan mempengaruhi keuntungan yang diperoleh industri rumah tangga ikan asin. Ada beberapa faktor yang dapat mempengaruhi keuntungan industri rumah tangga ikan asin di Desa Kuala Bubon Kecamatan Samatiga Kabupaten Aceh Barat ini yaitu, baik faktor sosial ekonomi maupun faktor jumlah produksi, harga jual, dan biaya-biaya yang dikeluarkan industri rumah tangga ikan asin dalam pengolahan ikan asin tersebut. Keuntungan diartikan sebagai selisih antara penerimaan perusahaan dan biaya total. Keuntungan ditentukan dengan menghitung dan membandingkan hasil penjualan total dengan biaya total. Keuntungan juga diartikan sebagai sejumlah uang yang diperoleh pengusaha sebagai laba kegiatan usahanya (Grace Masegi, 2014).

Umumnya pada proses peningkatan keuntungan pengolahan ikan industri rumah tangga di Desa Kuala Bubon Kecamatan Samatiga Kabupaten Aceh Barat ini, ikan yang telah mereka hasilkan oleh nelayan langsung dijual kepasar tanpa melalui proses pengolahan terlebih dahulu. Hal ini menyebabkan banyaknya ikan-ikan yang telah mereka hasilkan dijual murah agar ikan yang mereka hasilkan tidak cepat rusak atau busuk. Salah satu upaya yang dapat dilakukan untuk mengatasi masalah ikan mudah rusak adalah dengan peningkatan kegiatan- kegiatan industri rumah tangga dalam pengolahan hasil ikan. Yaitu dengan meningkatkan produksi pengolahan ikan pada industri rumah tangga.

Melalui industri rumah tangga ini diharapkan selain mampu meningkatkan pengolahan ikan juga dapat meningkatkan permintaan terhadap komoditas perikanan sebagai bahan baku industri pengolahan perikanan. Dan meningkatkan penerimaan industri rumah tangga pengolah ikan asin tersebut. Prinsip pengolahan ikan pada dasarnya bertujuan untuk melindungi ikan dari pembusukan atau kerusakan. Pembusukan terjadi akibat dari perubahan yang disebabkan oleh mikroorganisme dan perubahan-perubahan lain yang sifatnya merugikan. Selain untuk menghambat dan menghentikan aktivitas enzim maupun mikroorganisme, pengolahan ikan ini bertujuan untuk memperpanjang daya awet dan mendiversifikasikan produk olahan hasil perikanan.

Untuk meningkatkan keuntungan terhadap hasil ikan, mengingat ikan mudah rusak dan busuk, perlu dibuat alternatif pengolahan atau pengawetan guna memperpanjang masa simpan dan masa distribusinya. Salah satunya dengan cara penggaraman atau pengasinan ikan. Penggaraman atau pengasinan ikan merupakan proses menggunakan garam sebagai media pengawet, baik yang berbentuk kristal maupun larutan. Adapun berbagai cara penggaraman ikan yaitu penggaraman kering, penggaraman basah dan penggaraman campuran (Rabiatul Adwyah, 2007).

Berdasarkan survey awal diketahui bahwa pembuatan atau pengolahan ikan asin dilokasi penelitian di Desa Kuala Bubon Kecamatan Samatiga Kabupaten Aceh Barat masih menggunakan cara yang tradisional dalam pemanfaatan setiap tahapan proses sehingga hasil yang dicapai kurang optimal. Ikan asin yang dihasilkan masih belum optimal karena masih banyak terdapat hasil ikan yang telah diolah rasanya hambar, ikan masih lembek akibat dari kurang lamanya proses penjemuran, namun ada juga ikan yang terlalu asin akibat banyaknya proses penggaraman yang dilakukan, minimnya sarana dan prasarana pendukung usaha perikanan yang ada, kurang mendukungnya suasana lingkungan tempat pengolahan ikan, pengaruh musim yang menyebabkan banyak sedikitnya ikan yang dapat diproduksi oleh industri rumah tangga serta terbatasnya modal bagi industri rumah tangga pengolahan ikan guna untuk meningkatkan usaha. Sehingga usaha pengasinan ikan ini pada umumnya berskala kecil dan tidak berkembang secara baik dari tahun-tahun sebelumnya. Sedangkan 
jumlah industri pengasinan ikan ini semakin berkurang. Sehubung dengan hal ini maka penulis tertarik untuk melakukan penelitian yang menitik beratkan penelitian pada besarnya biaya, penerimaan, dan keuntungan yang diberikan dari pengolahan ikan menjadi ikan asin pada industri rumah tangga.

\section{KAJIAN PUSTAKA Konsep Produ ksi}

Produksi sering diartikan sebagai penciptaan guna, dimana kemampuan barang atau jasa untuk memenuhi kebutuhan manusia. Produksi meliputi semua aktifitas dan tidak hanya mencakup pembuatan barang-barang yang dapat dilihat. Produksi adalah suatu kegiatan untuk meningkatkan manfaat dengan cara mengkombinasikan faktor-faktor produksi kapital, tenaga kerja, teknologi. Produksi merupakan usaha meningkatkan manfaat dengan cara mengubah bentuk, memindahkan tempat, dan menyimpan (Soeharno, 2007).

Teori produksi terdiri dari dari beberapa analisa mengenai bagaimana seharusnya pengusaha (wiraswastawan) dalam tingkat teknologi tertentu mengkombinasikan berbagai macam faktor produksi untuk menghasilkan sejumlah produk tertentu seefisien mungkin. Agung (1994), mengemukakan bahwa produksi adalah hasil-hasil dari suatu proses atau aktifitas ekonomi dengan memanfaatkan beberapa masukan atau input. Soekartawi (1995) mengemukakan bahwa hasil akhir dari suatu proses berupa produk atau output dapat bervariasi disebabkan karena perbedaan kualitas dan kuantitas dari input faktor yang digunakan.

\section{Konsep Harga}

Anoraga (2000) menyatakan harga adalah variabel yang dapat dikendalikan dan dapat menentukan diterima tidaknya suatu produk oleh konsumen.Murah atau mahalnya harga suatu produk sangat relative sifatnya. Selanjutnya Fuad, dkk (2006), harga yaitu sejumlah konpensasi baik yang berupa uang maupun barang yang dibutuhkan untuk mendapatkan sejumlah kombinasi barang dan jasa.

Harga yang ditetapkan harus dapat menutup semua biaya yang telah dikeluarkan, jika harga ditetapkan terlalu tinggi, maka kurang menguntungkan karena pembeli dan volume penjualan berkurang.Harga jual adalah sejumlah biaya yang dikeluarkan perusahaan untuk memproduksi suatu barang atau jasa ditambah dengan persentase laba yang diinginkan pedagang.Untuk mencapai laba yang diinginkan oleh pedagang, maka pedagang akan melakukan daya tarik konsumen dengan cara menentukan harga yang tepat untuk produk yang terjual. Harga yang tepat adalah harga yang sesuai dengan kualitas produk suatu barang, dan harga tersebut dapat memberikan kepuasan kepada konsumen (Supriyono, 2007).

\section{Penerimaan (Revenue)}

Penerimaan adalah jumlah nilai atau hasil penjualan yang diterima dalam menjalankan usaha. Soekartawi (2005) menyatakan bahwa, total penerimaan dalam usahatani diperoleh dari produksi fisik dikalikan dengan harga produksi. Bila keadaan memungkinkan, maka sebaiknya petani mengolah sendiri hasil pertaniannya untuk mendapatkan kualitas hasil yang baik yang harganya relatif tinggi dan akhirnya juga akan mendatangkan total penerimaan yang lebih besar. 
Suratiyah (2009) menyatakan bahwa, penerimaan adalah perkalian antara jumlah produksi yang dihasilkan dengan harga jual produk. Secara matematis jumlah penerimaan dapat dituliskan sebagai berikut:

$T R=Y x P y$

Ket:

$T R=$ Penerimaan total $(\mathrm{Rp})$

$Y=$ Jumlah produksi

$P y=$ Harga dari hasil produksi $(\mathrm{Rp})$

\section{Keuntungan}

Keuntungan adalah selisih antara penerimaan total dan biaya-biaya (cost). Biaya ini dalam banyak kenyataan, dapat diklasifikasikan menjadi dua yaitu biaya tetap seperti sewa tanah, pembelian alat pertanian dan biaya tidak tetap seperti biaya yang dikeluarkan untuk membeli bibit, pupuk, obat-obatan, pembayaran tenaga kerja (Soekartawi, 2002).Keuntungan merupakan kegiatan pedagang yang mengurangkan beberapa biaya yang dikeluarkan dengan hasil penjualan yang di peroleh.Apabila hasil penjualan yang diperoleh dikurangi dengan biaya-biaya tersebut nilainya positif maka diperoleh keuntungan (laba) (Sukirno, 2005).

Rasyaf (2000) menyatakan setelah uang diterima dan dikurangi dengan biaya variabel, maka sisanya disebut keuntungan.Keuntungan adalah sejumlah uang yang diperoleh setelah semua biaya variabel termasuk biaya tetap operasional tertutupi. Hasil pengurangan positif berarti untung, hasil pengurangan negatif berarti rugi. Hasil pengurangan menjadi negatif bila biaya variabel terlalu besar. Mulyono (2000), menyatakan keuntungan margin adalah keuntungan yang bersifat kotor. Dari segi bisnis keuntungan ini bersifat semu karena ada unsur-unsur biaya yang tidak diperhitungkan, yaitu biaya tetap, sehingga besarnya keuntungan margin sama dengan selisih total output dengan biaya operasional.

Penerimaan marjinal adalah penerimaan tambahan yang diterima perusahaan ketika perusahaan meningkatkan output sebanyak satu unit tambahan.Dalam menentukan keuntungan secara ekonomi memerlukan sebuah fungsi, sehingga setiap pemecahaan masalah ekonomi dapat di jabarkan dengan sistematis.Rumus sederhana diatas merupakan pengertiaan dari Total Revenue (penerimaan total) - Total Cost (biaya total). Hal ini tidak terlepas dari keuntungan, keuntungan atau laba dalam ekonomi umumnya yaitu:

$\pi=T R-T C$

Ket:

$\pi=$ Keuntungan Industri Tahu Mekar $(R p / \mathrm{Bln})$

$T R=$ Total Penerimaan $(R p / B \ln )$

$T C=$ Total Biaya $(R p / B \ln )$

\section{Kelayakan Usaha}

Studi kelayakan bisnis merupakan penelitian terhadap rencana bisnis yang tidak hanya menganalisis layak atau tidak layaknya bisnis dibangun, tetapi juga saat dioperasionalkan secara rutin dalam rangka pencapaian keuntungan yang maximal untuk waktu yang tidak di 
terntukan (Umar, 2013). Sedangkan menurut Ibrahim (2003), yang menyatakan bahwa studi kelayakan bisnis merupakan bahan pertimbangan dalam mengambil suatu keputusan, apakah menerima atau menolak dari gagasan usaha atau proyek yang direncanakan.

Tujuan dilakukan studi kelayakan adalah untuk menghindari keterlanjuran penanaman modal yang terlalu besar untuk kegiatan yang ternyata tidak menguntungkan (Husen dan Suwarsono, 2000).

Aspek-aspek studi kelayakan bisnis terdiri atas:

1. Aspek pemasaran

2. Aspek teknis dan produksi

3. Aspek manajemen dan SDM

4. Aspek hukum

5. Aspek sosial

6. Aspek dampak lingkungan

7. Aspek finansial.

Soekartawi (2002) menyatakan Analisis kelayakan menggunakan $R / C$ ratio adalah perbandingan antara penerimaan dan biaya, besarnya $R / C$ ratio mempunyai prospek baik. Nilai $R / C$ ratio yang lebih besar dari 1 menunjukkan bahwa usaha yang dilakukan oleh industri atau perusahaan layak untuk diusahakan. Tingginya nilai $R / C$ ratio disebabkan oleh produksi yang diperoleh dan harga yang sangat berpengaruh terhadap penerimaan. Rumus yang digunakan untuk mendapatkan efisiensi usaha dalam $R / C$ ratio yaitu :

$R / C$ Rasio $=T R / T C$

Ket:

$R / C$ Ratio = Efisiensi Usaha

$T R=$ Total Revenue (penerimaan)

TC $\quad=$ Total Cost (biaya total)

\section{Penelitian Terdahulu}

Penelitian yang dilakukan oleh Umikalsum, (2014), yang berjudul Analisis usaha Pembuatan Tempe Kedelai Skala Rumahtangga di Kelurahan Bukit Sangkat Kecamatan Kalindo Kota Palembang. Adapun tujuan dari penelitian ini untuk mengetahui besarnya biaya, penerimaan, pendapatan, dan tingkat rentabilitas usaha industri tempe kedelai di Kelurahan Bukit Sangkal Kecamatan Kalidoni Kota Palembang. Hasil penelitian diperoleh kesimpulan bahwa biaya total rata-rata yang dikeluarkan oleh pengusaha tempe sebesar $\mathrm{Rp}$ 19.835.904. penerimaan rata-rata yang diperoleh setiap pengusaha adalah $\mathrm{Rp} 37.080 .000$ dan pendapatan rata-rata yang diperoleh sebesar $\mathrm{Rp} 17.244 .096$ per bulan. Rentabilitas dari usaha industri tempe kedelai skala rumahtangga tersebut adalah sebesar $86,9 \%$ hal ini berarti usaha industri tempe ini telah optimal dalam mendapatkan laba.

Penelitian yang dilakukan oleh, Verani Restia Wijaya, (2014), yang berjudul Pengaruh Peningkatan Harga Kedelai terhadap Keuntungan dan Nilai Tambah Industri Tahu di Desa Leuweung Kolot Kecamatan Cibungbulang Kabupaten Bogor. Penelitian ini bertujuan menganalisis pengaruh kenaikan harga kedelai terhadap struktur biaya, keuntungan, dan nilai tambah pada industri tahu di Desa Leuweung Kolot. Analisis yang digunakan terdiri dari analisis keuntungan, analisis penerimaan dan $\mathrm{R} / \mathrm{C}$ rasio, dan analisis nilai tambah menggunakan metode Hayami. Berdasarkan hasil penelitian yang telah dilakukan 
menunjukkan bahwa kenaikan harga kedelai mempengaruhi struktur biaya dan keuntungan industri tahu. Peningkatan pada keuntungan yang diterima didasarkan pada strategi yang dilakukan oleh industri tahu dengan meningkatkan harga jual tahu dan memperkecil ukuran tahu. Begitupun dengan analisis nilai tambah yang menunjukkan bahwa kenaikan harga kedelai juga mempengaruhi nilai tambah yang dihasilkan oleh industri tahu di Desa Leuweung Kolot.

\section{METODE PENELITIAN}

Penelitian yang telah lakukan merupakan penelitian deskriptif kualitatif. Penelitian dilakukan pada industri rumah tangga pengolah ikan di Desa Kuala Bubon Kecamatan Samatiga Kabupaten Aceh Barat. Populasi adalah seluruh industri rumah tangga pengolah ikan yang berjumlah 40 industri. Sampel ditunjuk secara sengaja (purposive) yaitu semua pemilik industri rumah tangga yang berjumlah 30 industri rumah tangga pengolah ikan menjadi ikan asin dengan kriteria : 1) Usaha industri rumah tangga yang telah dijalankan minimal 5 tahun ;2) Usaha industri rumah tangga yang mengelola ikan asin sebagai mata pencaharian utama di Desa Kuala Bubon Kecamatan Samatiga Kabupaten Aceh Barat. Teknik pengumpulan data dalam penelitian ini dengan wawancara. Jenis dan sumber data dalam penelitian ini menggunakan data primer.

Teknik analisis data menggunakan rumus :

$\pi=\mathrm{TR}-\mathrm{TC}$

$\pi \quad=$ keuntungan ikan asin (profit)

TR $\quad=$ penerimaan total ikan asin (P.Q)

P.Q = harga ikan asin dikalikan dengan jumlah yang dijual

TC = biaya total ikan asin

\section{HASIL DAN PEMBAHASAN}

\section{Deskripsi Wilayah Penelitian}

Desa Kuala Bubon merupakan salah satu desa yang terdapat di Kecamatan Samatiga Kabupaten Aceh Barat. Desa Kuala Bubon ini juga merupakan salah satu desa yang mengembangkan industri rumah tangga dalam bidang pengolahan ikan menjadi ikan asin dalam bidang pengolahan pengasin ikan atau penggaraman ikan. Usaha industri rumah tangga di desa Kuala Bubon ini merupakan industri yang berskala kecil.

\section{Produksi, Variasi, Jenis, Tingkat Harga Ikan Asin}

Produksi adalah suatu kegiatan yang mengubah input menjadi output. Kegiatan tersebut dalam ekonomi biasanya dinyatakan dalam fungsi produksi. Fungsi produksi menunjukkan jumlah maksimum output yang dapat dihasilkan dari pemakaian sejumlah input dengan menggunakan teknologi tertentu (Sugirto, $d k k, 2005$ ).

Rata-rata produksi ikan asin pada industri rumah tangga pengolah ikan di Desa Kuala Bubon Kecamatan Samatiga Kabupaten Aceh Barat adalah sebesar 26,6 kg. Sedangkan 
variasi ikan asin para industri rumah tangga pengolah ikan di Desa Kuala Bubon ini masih berfokus pada variasi ikan asin yang mereka olah. Tabel 1 menunjukkan variasi ikan yang diproduksi masing-masing indstri rumah tangga pengolah ikan di Desa Kuala Bubon Kecamatan Samatiga Kabupaten Aceh Barat.

Tabel 1. Variasi Jenis Ikan Asin dan Tingkat Harga Per Bulan

\begin{tabular}{llc}
\hline No & Variasi Jenis Ikan Asin & Harga/kg (Rp) \\
\hline 1 & Ikan sepat & $35.000,00$ \\
2 & Ikan gabus & $70.000,00$ \\
3 & Ikan bulan-bulan & $26.000,00$ \\
\hline
\end{tabular}

Sumber : Diolah dari data primer, 2017

Tabel 1. Menunjukkan bahwa variasi, harga dan jenis ikan yang dijual oleh masingmasing industri rumah tangga berbeda-beda, dimana harga $/ \mathrm{kg}$ ikan asin sepat senilai Rp.35.000,00, ikan asin gabus senilai Rp. 70.000,00 sedangkan harga ikan asin jenis bulanbulan adalah seharga Rp.26.000,00.

\section{Biaya Produksi}

Biaya produksi dapat adalah sebagai semua pengeluaran yang dilakukan oleh perusahaan untuk memperoleh faktor-faktor produksi dan bahan-bahan mentah yang akan digunakan untuk menciptakan barang-barang yang diproduksikan perusahaan tersebut (Sadono Sukirno, 2012).

Total biaya produksi merupakan akumulasi dari biaya tetap dan biaya variabel. Biaya tetap yang digunakan dalam industri rumah tangga yaitu biaya penyusutan peralatan dan biaya tempat usaha. Adapun yang termasuk dalam biaya penyusutan peralatan yang digunakan industri rumah tangga adalah biaya penyusutan pisau, biaya penyusutan kawat, biaya penyusutan baskom, dan biaya penyusutan kayu. Sedangkan Biaya variabel industri rumah tangga yaitu biaya bahan baku yang digunanakan dalam pengolahan ikan asin yang berupa pembelian ikan basah dan pembelian garam secukupnya, biaya tagihan listrik, biaya tagihan air, serta biaya tenaga kerja dalam proses pengolahan ikan basah menjadi ikan asin. Tabel 2 menunjukkan rekapitulasi biaya produksi pada industri rumah tangga pengolah ikan di Desa Kuala Bubon Kecamatan Samatiga Kabupaten Aceh Barat.

Tabel 2. Rekapitulasi Biaya Produksi Pada Industri Rumah Tangga Pengolah Ikan

\begin{tabular}{llc} 
No & Jenis Biaya & Jumlah $(\mathrm{Rp})$ \\
\hline 1 & Biaya tetap & 117.102 \\
2 & Biaya variabel & 2.500 .100 \\
\hline \multicolumn{2}{l}{ Total } & 2.617 .202 \\
\hline
\end{tabular}

Sumber : Diolah Dari Data Primer, 2017

Pada tabel 2 menunjukkan bahwa industri rumah tangga pengolah ikan ini secara umum rata-rata biaya tetap industri pengolah ikan asin adalah sebesar Rp. 117.102 per bulan. Sedangkan biaya variabel adalah sebesar Rp.2.500.100 per bulan.

Adapun biaya variabel yang tidak diperhitungkan dalam industri rumah tangga ini yaitu biaya transportasi, hal ini dikarenakan pemasaran pada penjualan ikan asin ini dijual langsung kepada agen yang datang satu minggu sekali untuk membeli ikan asin yang 
diproduksi oleh industri rumah tangga. Sehingga para industri rumah tangga tidak lagi memperhitungkan biaya transportasi untuk penjualan ikan asin.

Secara umum rata-rata biaya produksi yang dikeluarkan oleh industri rumah tangga pengolah ikan di Desa Kuala Bubon Kecamatan Samatiga Kabupaten Aceh Barat adalah sebesar Rp.2.617.202 per bulan.

\section{Tingkat Keuntungan Usaha dan Analisis R/C}

Keuntungan merupakan selisih antara penerimaan dengan biaya. Keuntungan juga berarti penghasilan bersih yang diterima oleh produsen, sesudah dikurangi dengan biaya- biaya produksi. Keuntungan atau laba adalah pendapatan dikurangi biaya total (irwan,2010). Tabel 3 menujukkan keuntungan yang diperoleh industri rumah tangga pengolah ikan setelah dikurangi dengan total biaya-biaya yang dikeluarkan pada saat proses produksi ikan asin.

Tabel 3. Keuntungan dan R/C Pada Industri Rumah Tangga Pengolah Ikan di Desa Kuala Bubon Kecamatan Samatiga Kabupaten Aceh Barat Per Bulan

\begin{tabular}{llll}
\hline Penerimaan & Total Biaya & Keuntungan & Rasio R/C \\
\hline 3.953 .333 & 2.617 .202 & $1.336,131$ & 1,52 \\
\hline
\end{tabular}

Tabel 3 menunjukkan keuntungan industri rumah tangga pengolah ikan menjadi ikan asin sebesar Rp.1.336.131 per bulan dengan rasio R/C sebesar 1,52. Maka dapat disimpulkan bahwa usaha industri rumah tangga pengolah ikan menjadi ikan asin di Desa Kuala Bubon Kecamata Tanah Putih Kabupaten Aceh Barat tergolong layak untuk dijalankan karena nilai rasio R/C lebih dari 1 . Artinya bahwa setiap Rp. 1 biaya produksi yang dikeluarkan oleh pengelolan industri ruamah tangga mampu memberikan pengembalian berupa penerimaan lebih dari Rp.1,52. Artinya total penerimaan masih lebih besar dari total biaya produksi dan kegiatan usaha industri rumah tangga pengolah ikan menjadi ikan asin di Desa Kuala Bubon Kecamatan Samatiga Kabupaten Aceh Barat ini masih mengalami keuntungan setiap bulannya.

\section{Implikasi Hasil Penelitian Terhadap Pendidikan}

Penelitian bermanfaat untuk memperkaya materi peran pelaku kegiatan ekonomi materi pokoknya adalah pelaku-pelaku kegiatan ekonomi : rumah tangga konsumsi (konsumen), rumah tangga produksi (produsen), pemerintah, dan peran pelaku kegiatan ekonomi dalam silabus SMA kurikulum 2013 kelas X SMA. Hasil penelitian membahas tentang industri rumah tangga produsen, teori produksi, dan biaya-biaya yang dikeluarkan pada saat industri rumah tangga memproduksi suatu produk yang akan dipasarkan kepada masyarakat setempat maupun masyarakat luar kota. Manfaat lain dari hasil peneletian sebagai referensi untuk meneliti bagaimana industri rumah tangga produsen memasarkan produknya dan mengembangkan usahanya agar tetap berkembang sesuai keinginan produsen dan juga dapat memenuhi selera maupun kebutuhan konsumen.

Penelitian juga bermanfaat untuk memperkaya materi permasalahan tenaga kerja, sistem upah dan kesempatan kerja didalam silabus Kurikulum 2013 untuk tingkat SMA pada mata pelajaran ekonomi kelas X. Penelitian bermanfaat Karena didalam pembahasan hasil 
penelitian membahas bagaimana sistem upah diterapkan pada tenaga kerja dan bagaimana perhitungan Hari Orang Kerja (HOK) pada suatu industri rumah tangga produsen. Manfaat lain dari penelitian sebagai referensi bagi pendidik agar lebih mudah untuk mejadikan contoh yang nyata pada saat menjelaskan kepada peserta didik tentang permasalahan upah tenaga kerja atau perhitungan yang diterapkan pada Hari Orang Kerja (HOK).

\section{SIMPULAN DAN REKOMENDASI}

Berdasarkan hasil penelitian yang telah dilakukan pada industri rumah tangga pengolah ikan asin di Desa Kuala Bubon Kecamatan Samatiga Kabupaten Aceh Barat diperoleh kesimpulan sebagai berikut :

1. Industri rumah tangga pengolah ikan menjadi ikan asin dalam proses produksinya mengeluarkan biaya-biaya produksi berupa biaya tetap dan biaya variabel. Yang termasuk pengeluaran biaya tetap yaitu biaya penyusutan, dan biaya sewa tempat. Sedangkan pengeluaran untuk biaya variabel yaitu biaya bahan baku, biaya tagihan listrik, biaya tagiha air, dan biaya tenaga kerja. Secara umum biaya produksi yang dikeluarkan oleh industri rumah tangga pengolah ikan di Desa Kuala Bubon yaitu sebesar Rp. 2.617.202 per bulan.

2. Industri rumah tangga pengolah ikan menjadi ikan asin setiap bulannya memperoleh keuntungan sebesar Rp. 1.336.131, dengan tingkat rasio R/C sebesar 1,52. Artinya usaha industri rumah tangga pengolah ikan menjadi ikan asin di Desa Kuala Bubon Kecamatan Samatiga Kabupaten Aceh Barat tergolong layak untuk dijalankan.

\section{Rekomendasi}

Rekomendasi yang dapat diberikan dari hasil penelitian yang telah dilakukan pada usaha pengolah ikan menjadi ikan asin adalah :

1. Sebaiknya industri rumah tangga pengolah ikan tidak hanya memproduksi tiga jenis ikan asin. Tetapi masih bisa mengolah jenis ikan lain seperti ikan asin baung, tuman, serta ikan asin lais, karena di lokasi tempat pengusaha pengolah ikan mudah memperoleh bahan baku untuk jenis ikan baung, tuman, dan ikan lais.

2. Sebaiknya industri rumah tangga pengolah ikan tidak hanya mengolah ikan menjadi ikan asin, tetapi masih bisa mengolah ikan salai untuk memperbanyak hasil produksi dan meningkatkan keuntungan.

3. Untuk meningkatkan keuntungan usaha sebaiknya industri rumah tangga pengolah ikan diberikan pelatihan tentang bagaimana pengembangan dari pengolahan ikan menjadi makanan ringan seperti pembuatan kue dari ikan agar usaha industri rumah tangga pengolah ikan tetap bisa berlangsung jangka panjang.

4. Sebaiknya pemerintah bisa membantu mengembangkan usaha pengolah ikan menjadi ikan asin lebih produktif, dengan cara memberikan bantuan modal usaha. 


\section{DAFTAR PUSTAKA}

Akhmad Fauzi. 2004. Ekonomi Sumber Daya Alam dan Lingkungan. PT Gramedia Pustaka Utama. Jakarta.

Grace Masengi.2014. Analisis Keuntungan Usaha Rumah Makan El-Shadai di Kawasan Wisatakuliner Wakeke Manado. Jurnal : 1-25. Fakultas Pertanian Universitas Sam Ratulangi. Manado.

Rabiatul Adawyah, 2007. Pengelolaan dan Pengawetan Ikan. PT Bumi Aksara. Jakarta.

Sadono, Sukirno.2012. Mikro Ekonomi. PT Raja Grafindo Persada. Jakarta.

Soeharno. 2007. Teori Mikroekonomi. Andi Yogyakarta.

Sugirto, dkk. 2005. Ekonomi Mikro. PT Gramedia Pustaka Utama. Jakarta. 